\title{
The Determinants of Foreign Direct Investment in the African Union
}

\author{
Caroline Kariuki
}

\begin{abstract}
This paper will examine the factors that influence foreign direct investment (FDI) flows into African countries. FDI flows are important for African nations as they promote economic development. Estimation results using the Least Squares Dummy Variable model also known as the fixed effects model indicate that i) a high economic risk has a negative and significant effect on FDI flows into Africa ii) both political risk and financial risk have a negative but insignificant impact on FDI inflows iii) there is a positive and significant relationship between the commodity price index performance and FDI inflows iv) the good performance of stock markets in developed countries has a positive and significant impact on FDI inflows v) an increase in the infrastructure of a country has a positive and significant effect on FDI inflows vi) an increase in openness to trade has a positive and significant effect on FDI inflows vii) the amount of FDI received in the previous year by African countries is significant in influencing the FDI flows that come into the African continent in the current year. Annual data from 1984 until 2010 using 35 African countries is used for this panel study.
\end{abstract}

Index Terms-Africa, foreign direct investment, long term capital movements, panel data.

\section{INTRODUCTION}

\section{A. Background}

Foreign Direct Investment (FDI) is an important topic for developing nations as it brings with it economic development, access to managerial skills, financial resources, marketing expertise, and leads to increased employment. This type of investment occurs when a firm invests to produce a product in a foreign country or when a firm buys an existing enterprise in a foreign country [1]. Inward FDI flows to Africa have been on the rise as countries have further opened up their economies to international trade and initiated economic and political reforms. In 2012, FDI flows into the continent stood at a value of approximately US $\$ 50.04$ billion [2]. A number of African nations are also experiencing strong economic growth. An analysis by the International Monetary Fund (IMF) and The Economist finds that over the decade to 2010 six of the world's ten fastest growing economies were in Sub-Saharan Africa [3].

\section{B. Significance of the Study}

Past studies that have examined FDI flows into Africa have not included the performance of the commodity price index as one of the variables that may influence FDI flows into African countries. This research will add new information to literature by demonstrating that the change in commodity

Manuscript received October 16, 2013; revised December 20, 2013.

C. Kariuki is with the Department of Economics and Finance, Curtin University, Australia (e-mail: wanjiruck@gmail.com). prices can be used to predict whether or not there will be an increase of inward FDI to Africa. A study by [4] was undertaken to examine investment response to commodity price shocks. Reference [4] finds that investment booms in response to commodity price shocks are likely but not certain to take place. A boom at the end of the commodity price shock may also occur. However, [4] did not focus on FDI and the study only included four African countries. This study has a focus on FDI into Africa and uses data from 35 African nations.

Previous studies have also not included the performance of stock markets in various developed countries as one of the variables that may influence FDI flows into African nations. This research will include the performance of stock markets in developed countries as one of the variables thus contributing new information to literature. The performance of stock markets in developed countries may be used to provide signals to African nations as to whether or not they can expect an increase of FDI inflows from these developed countries. For example, stock markets in many developed nations were weak during the global financial crisis of 2008 . The weak stock markets in developed countries contributed to the economic slowdown faced by these developed countries. The decreased economic growth had an adverse effect on capital outflows and as a result, Africa experienced a decrease in inward FDI from developed countries in 2009.

The economic, financial and political risk ratings produced by the International Country Risk Guide (ICRG) have been used in this research to represent the economic health, financial health, and political stability of African countries. The use of the ICRG risk ratings will allow researchers to better understand if these risk ratings can be used as a substitute for individual variables that are usually included in research to account for economic, financial or political risk in a country.

Previous studies that have examined FDI flows into African countries have used a number of macroeconomic variables to account for economic, financial, and political risk in a country. Other studies for example [5]-[8] have used some components of the ICRG risk ratings in their research

This research uses all the three ICRG risk ratings and their components (i.e. economic risk rating, financial risk rating, and political risk rating).

\section{Countries Examined in this Study}

Countries included in the study have been chosen on the basis that they are a member of the African Union (AU) and have ICRG (economic, financial, and political risk) data available starting from 1984 to 2010 . Thirty five countries fall into this category. These are Algeria, Angola, Botswana, Burkina Faso, Cameroon, Côte d'Ivoire, Democratic Republic of the Congo, Egypt, Ethiopia, Gabon, Gambia, 
Ghana, Guinea, Guinea-Bissau, Kenya, Liberia, Libya, Madagascar, Malawi, Mali, Mozambique, Namibia, Niger, Nigeria, Republic of the Congo, Senegal, Sierra Leone, South Africa, Sudan, United Republic of Tanzania, Togo, Tunisia, Uganda, Zambia, and Zimbabwe.

\section{LITERATURE REVIEW}

Large domestic markets are found to be important in attracting inward FDI especially if foreign firms wish to sell their products in the host nation. Over the years, there has been an increase in the amount of FDI that is aimed at buyers in host countries (market seeking FDI). The economic growth of African countries as well as the increase in population has been an incentive for foreign firms to make market seeking investments in the continent. Reference [5], [9] show that large local markets are significant in attracting FDI into Sub-Saharan Africa (SSA). Reference [10] finds that there is a positive relationship between market size (measured using urban population size) and FDI flows into Africa. Based on a cointegration analysis of 19 countries, [11] discovers that growing markets are a long run determinant of FDI in SSA. Reference [12] who researches on FDI into developing nations finds market size an important consideration for foreign investors. Reference [13] use a panel of 36 countries and find that the size of the economy influences FDI flows into Middle East and North African (MENA) countries.

Natural resources have attracted many foreign investors into Africa. Research undertaken by [5] finds that the availability of natural resources promotes FDI flows into SSA. However, small countries and/or those that lack natural resources can obtain inward FDI by improving their institutions to control factors like corruption, ensuring that the law is well enforced, and the legal system is impartial [5]. Fifty three African countries were examined by [10] who concludes that natural resource endowments (especially oil) attract substantial FDI into Africa. Reference [14] examined the determinants of FDI into Africa and find natural resource availability to be significant in influencing FDI inflows. Natural resources are also found to be a significant factor in influencing FDI inflows into African nations by [15]. Reference [13] concludes that natural resources are an important determinant of FDI flows into MENA countries.

Good infrastructure in a country assists in reducing the operating costs of businesses. There is currently a huge presence of Chinese firms in Africa working on infrastructure projects such as roads, railways, bridges, ports, and building construction. Infrastructure is important in attracting FDI flows into SSA as shown by [5]. Reference [16] researched the motivating factors and policy issues that influence FDI in SSA. These researchers find infrastructure to be one the factors that influences FDI inflows. Furthermore, governments need to improve on the quality of infrastructure so as to reduce the transaction costs faced by foreign investors. Reference [17] explain that poor infrastructure is one of the reasons Africa has been receiving low levels of FDI in comparison to other developing regions.

However, not all authors find infrastructure to be a significant variable. After examining 29 countries in Africa, [14] find infrastructure insignificant in influencing FDI flows. These researchers find that poor infrastructure may not deter foreign investors because factors such as natural resources, openness to trade, and other macroeconomic variables may be more significant. The earlier research of [18] finds that the level of infrastructure in SSA countries is not significant in influencing FDI flows into Africa.

Openness to trade is another significant factor that may influence the FDI flows into a country. Reference [18] finds openness to trade a significant determinant of FDI flows into SSA. Reference [19] also looked into the relationship between trade openness and FDI. These researchers conclude that increased openness in the economy has a positive impact on FDI flows into Africa. As part of their research [19] mentions that the service sector has more barriers than any of the other sectors. Their results state that further trade liberalization is likely to increase FDI flows into service sectors such as telecommunications, banking, finance, insurance, transport, retail, business, and legal services. References [9], [14], [15], and [20] find that trade openness plays a significant role in attracting more FDI flows into Africa. However, it is important for a host nation to be prudent when making their decision to allow foreign investment. This decision should be made with the host country's national interests in mind.

High rates of inflation can be a cost of doing business as foreign firms may enter into long-term contracts in the host nation. When the actual inflation rate turns out to be very different from the anticipated inflation rate, foreign firms may lose out as their purchasing power decreases. A high rate of inflation is found to have a negative effect on attracting inward FDI by [15]. Reference [21] also finds the inflation rate to have a negative relationship with FDI flows into Africa. The finding from [5] shows that a low level of inflation has a positive effect on FDI flows into SSA. Reference [14] as well as [22] find that inflation is a significant variable which influences foreign investors who wish to invest in Africa. Reference [23] shows that FDI is correlated to the level of inflation in developing nations. A low level of inflation is likely to encourage more FDI inflows as it indicates that an economy has sound macroeconomic policies.

The exchange rate has also been considered to be important in determining FDI flows into a country. Reference [19] looked into the relationship between real exchange rates and FDI in 38 African countries. They find an inverse relationship between real exchange rate appreciation and FDI inflows. Reference [24] agrees that exchange rates play an important role in attracting FDI. The aim of their paper was to examine how exchange rate volatility impacts FDI inflows into Ghana. Their research concludes that the real exchange rate volatility has a negative influence on FDI inflows. This means that exchange rate volatility, which is a measure of risk, decreases FDI inflows. Both [11] and [21] find exchange rates to be important in influencing FDI flows into Africa.

Research from [16] highlights that political economy considerations strongly influence FDI location decisions in SSA. Reference [7] agrees that political risk is a major component that influences FDI flows into Africa. Their research concludes that government stability, internal and external conflicts, law and order, ethnic tensions, and bureaucratic quality are important determinants of FDI. Corruption and democratic accountability are also important, 
but to a lesser degree. In their research, [17] state that political instability in Africa is a factor that has been responsible for low FDI inflows. It is important for a host country to have good governance (political stability, accountability, regulatory burden, rule of law) as it influences FDI flows into Africa [22]. Reference [25] uses panel data from 117 countries and shows higher corruption levels decrease FDI inflows. Political risk has also been found to be an important determinant of FDI into China and India from the research by [26].

However, not all researchers looking into the topic of FDI seem to think that political stability is an important determinant. Based on the results from the researcher's data, [18] decided not to investigate further into political risk as the variable was insignificant. This is supported by findings in Angola between 1998 and 1999. During this time Angola's FDI inflows ranked first in SSA although the country was politically unstable due to civil war. Reference [19] also agrees with [18]. They too found that the political stability variable in their data was insignificant. The research undertaken by [14] finds that political rights in a country are not significant in influencing FDI flows into African countries.

Government policies are influential in attracting FDI flows into a country. Reference [5] shows through research that government policies are significant in influencing FDI flows into SSA. Governments can offer incentives to potential foreign investors in the form of tax holidays, tax rebates, investments in infrastructure among others. Governments should also work to ensure that there is more transparency in their economies. Policies that aim to train and upgrade the skills of the labour force are encouraged as this increases human capital.

The findings from [16] show that governments in SSA need to improve on their regulatory environment. In other words, there should be laws that encourage people to do business in an economy. Reference [17] mention that African countries should improve their relations with existing investors and offer them incentives to come and invest more into the continent. The results from [27] show that the high volatility of fiscal and business regulations reduces the flow of FDI into transition economies. Reference [28] who examined nine Latin American countries finds that FDI inflows decrease when government policy changes lead to higher trade barriers, higher taxes, restrictions on foreign investment, a more repressive financial system, additional price controls, and wage controls.

Bilateral investment treaties ${ }^{1}$ have been used in many developing countries and are found to have a positive effect on inward FDI. Reference [30] finds that a higher number of bilateral investment treaties increase FDI flows into a developing country. The results from [31] indicate that countries involved in Preferential Trade Agreements (PTAs) ${ }^{2}$ receive higher inward FDI flows. It is contended by [31] that when countries are members of PTAs or international trade agreements they are less likely to go back on their

${ }^{1}$ Bilateral investment treaties are agreements between two nations for the reciprocal, encouragement, promotion and protection of investments made in each other's countries [29].

${ }^{2}$ Preferential Trade Agreements (PTAs) - Trade agreements between several countries to reduce tariffs on certain goods. commitments due to the high costs that will be incurred when terms of the agreement are broken.

The presence of foreign firms in an economy may be an incentive for other multinational companies to come and invest into a host nation. The results from [32] indicate that the presence of other foreign firms in a country appears to be important in influencing FDI flows. Their research is based on data from 27 advanced and emerging countries. A firm interested in making an FDI decision in another country may encourage their suppliers to follow them into the new country. Some firms may follow other multinational companies as it signals a good business environment and reduces their uncertainty. This is known as agglomeration. Reference [33] finds that agglomeration is an important determinant of FDI inflows for Eastern European and Baltic countries.

The flow of foreign aid into a host country has also been considered to be a determinant of FDI. Conditions are usually attached to the aid given to developing nations with some of them aimed at improving the economic and financial conditions of the recipient country. Research from [34] was carried out on 126 developing nations and found that overall IMF involvement in a certain country tends to encourage FDI from the United States of America. However, the amount of FDI flows into a host country depends on the specific IMF program taken. Indeed, other developed nations may have a preference to invest into nations that have received assistance through development aid. It is anticipated that with the right management, countries that have received development aid will move towards overcoming poverty through changes in areas such as: education, health, water, sanitation, infrastructure, and food security. As a result these countries are more likely to achieve economic growth. Good governance and developed financial markets help reinforce the positive effects of aid [35].

\section{MethodOlOGY AND MODEL}

\section{A. Econometric Model}

A dynamic panel data model is estimated and used to analyse the data. This model will also provide information on the effect that FDI inflows received into Africa in the previous year have on current FDI inflows. As such, the lagged dependent variable $\left(F D I_{i-1}\right)$ is included as an explanatory variable in the dynamic panel data model. The FDI variable is lagged by one year. This model is estimated using the Least Squares Dummy Variable (LSDV) technique. The variables have been transformed into natural logarithms, allowing the coefficient estimates to be interpreted as elasticities.

$$
\begin{aligned}
& \ln \left(F D I_{i t}\right)=\alpha_{i}+\lambda_{t}+\beta_{1} \ln \left(F D I_{i t-1}\right)+\beta_{2} \ln \left(E R_{i t}\right)+ \\
& \beta_{3} \ln \left(F R_{i t}\right)+\beta_{4} \ln \left(P R_{i t}\right)+\beta_{5} \ln \left(\text { Commindex }_{i t}\right) \\
& +\beta_{6} \ln \left(\text { Worldindex }_{i t}\right)+\beta_{7} \ln \left(\text { Capformation }_{i t}\right)+ \\
& \beta_{8} \ln \left(\text { Open }_{i t}\right)+u_{i t}
\end{aligned}
$$

The subscript $i$ refers to an individual country and $t$ refers to years from 1984 to $2010 . \alpha_{i}$ is the individual country effect which is specific to the individual cross sectional country $i$. $\lambda_{t}$ is the country invariant time effect and $\mathrm{u}_{\mathrm{it}}$ is the residual term for country $i$ at time $t$. 


\section{B. Description of Variables}

Foreign Direct Investment (FDI)-Net inflow of investment made to acquire a lasting interest (10\% or more voting stock) in an enterprise operating in an economy other than that of the investor.

Economic risk rating (ER)-Index measuring GDP per head, real GDP growth, annual inflation rate, budget balance as a percentage of GDP, and current account as a percentage of GDP in a country.

Financial risk rating ( $F R$ )-Index measuring foreign debt as a percentage of GDP, foreign debt services as a percentage of exports of goods and services, current account as a percentage of exports of goods and services, net international liquidity as months of import cover, and exchange rate stability in a country.

Political risk rating (PR)-Index measuring government stability, socioeconomic obligations (socioeconomic pressures in a country relating to unemployment, consumer confidence and poverty), investment profile, internal conflict, external conflict, corruption, military in politics, religious tensions, law and order, ethnic tensions, democratic accountability (government's response to its citizens), and bureaucracy quality (institutional strength) in a country.

Commodity price index (Commindex)-UNCTAD Commodity Price Index tracking the price changes of commodities exported from developing countries in the food, agricultural, minerals, ores, metals, and energy sectors.

World stock market index (Worldindex)-The MSCI World Index tracks the performance of major stock markets in developed nations. These countries are Australia, Austria, Belgium, Canada, Denmark, Finland, France, Germany, Greece, Hong Kong, Ireland, Israel, Italy, Japan, Netherlands, New Zealand, Norway, Portugal, Singapore, Spain, Sweden, Switzerland, U.K., and U.S.

Gross fixed capital formation (Capformation)-This variable is used as a proxy for infrastructure. Gross fixed capital formation includes land improvements, plant, machinery and equipment purchases, the construction of roads and railways, schools, offices, hospitals, private residential dwellings as well as commercial and industrial buildings [36].

Openness to trade (Open)-This is a measure of the ratio of imports and exports to a country's GDP.

The net FDI inflows, gross fixed capital formation, and openness to trade data are obtained from The World Bank. The economic, financial and political risk rating data are acquired from the Political Risk Services Group database and produced by the ICRG. The Commodity Price Index is from the UNCTAD Statistics database and the MSCI World Price Index is from DataStream. Annual data from 1984 to 2010 are used for this study.

\section{Hypotheses}

\section{1) Economic risk}

Economic risk assesses a country's current economic strengths and weaknesses. Countries that experience slow economic growth and development may find themselves receiving less FDI as there is less of an incentive for foreigners to invest in the country.

Hypothesis: there is a negative and significant relationship between economic risk and inward FDI.

\section{2) Financial risk}

This variable is used as a proxy for financial health and strength in a country. Research undertaken by [37] finds heavy debt in African countries discourages FDI. Reference [19] find an inverse relationship between real exchange appreciation and inward FDI to African countries. Reference [21] notes that unexpected movements in the exchange rate may affect expected rates of return to investment, which has an impact on FDI flows into Africa.

Hypothesis: there is a negative and significant relationship between financial risk and inward FDI.

\section{3) Political risk}

The political risk rating measures a country's political stability. Government stability, internal and external conflicts, law and order, ethnic tensions, and bureaucratic quality are important determinants of FDI [7]. Researchers such as [5], [7], [16], [17], [20], [22], [38], [39] show that the political situation in a country is an important consideration for foreign investors.

Hypothesis: there is a negative and significant relationship between political risk and inward FDI.

\section{4) Commodity price index}

It is anticipated that as demand for commodities increases and commodity prices continue to rise, there will be an increase of FDI into Africa as foreign investors seek to benefit from this trade.

Hypothesis: there is a positive and significant relationship between the commodity price index and inward FDI.

\section{5) World stock market index}

Research carried out by [40] on the international financial markets, mentions that stock prices appear to granger cause GDP. This means that the changes in the stock prices help in the prediction of GDP. Therefore an increase in the world stock market index may indicate economic growth (an increase in GDP) in the economies of developed countries. This will in turn lead to increased outflows of foreign investment from these developed nations with some of the investments flowing into African countries.

Hypothesis: there is a positive and significant relationship between the world stock market index and inward FDI.

\section{6) Gross fixed capital formation}

Gross fixed capital formation is used as a proxy for infrastructure. With good infrastructure it becomes more efficient to transport goods from one place to another, communicate with people involved in business operations through the use of technology, have buildings that are well set up and have uninterrupted power, and water supplies.

Hypothesis: there is a positive and significant relationship between gross fixed capital formation and inward FDI.

\section{7) Openness to trade}

Openness to trade deals with the trade restrictions that are placed on goods and services coming into a country. When a country is open to trade with other nations it is expected that there will be more FDI flows coming into that country. This is because openness to trade tends to promote free trade which encourages more investment.

Hypothesis: there is a positive and significant relationship between openness to trade and inward FDI. 


\section{FINDINGS}

\section{A. Dynamic Panel Data Model}

The dynamic panel data model is estimated using the LSDV model, which is also the fixed effects model. The LSDV technique can be used to estimate a dynamic panel data model when the data has a long time period (large T). The best fit for the model is found to be a lag of one year.

\begin{tabular}{lllll}
\multicolumn{5}{c}{ TABLE I: DYNAMIC PANEL DATA MODEL } \\
\hline Variable & Coefficient & Std. Error & t-stat & p-value \\
\hline lnfdi(-1) & 0.42 & 0.07 & 6.12 & $0.00^{* * *}$ \\
lneconrisk & -0.61 & 0.25 & -2.47 & $0.01^{* *}$ \\
lnfinrisk & -0.13 & 0.16 & -0.81 & 0.42 \\
lnpolrisk & -0.47 & 0.44 & -1.06 & 0.29 \\
lncommindex & 0.53 & 0.20 & 2.67 & $0.01 * *$ \\
lnworldindex & 0.58 & 0.12 & 4.87 & $0.00^{* * *}$ \\
lncapformation & 0.28 & 0.13 & 2.16 & $0.03 * *$ \\
lnopen & 0.81 & 0.30 & 2.71 & $0.01 * *$ \\
c & 4.55 & 1.96 & 2.32 & 0.02 \\
& & & & \\
Adjusted R & & & & \\
Durbin Watson & 0.78 & & & \\
Standard error & 1.94 & & & \\
of regression & 1.07 & & & \\
F-statistic & & & & \\
(p-value) & 0.00 & & & \\
\hline Significant p-values at $* 10 \%, * * 5 \%$ and ***1\%. & \\
\end{tabular}

\section{B. Results}

The results from the dynamic panel data model Table I show that the level of economic risk has a negative and significant relationship with FDI inflows. A $1 \%$ increase in the level of economic risk will lead to a decrease of FDI flows into African countries by $0.61 \%$. The financial risk has a negative relationship with the FDI flows coming into Africa. However, financial risk is insignificant in influencing FDI flows into African nations. The political risk variable also has a negative coefficient but is insignificant in influencing FDI flows into Africa. The results suggest that foreign investors are still willing to make investments in African countries even in the presence of financial and political risk in a country.

The performance of the commodity price index has a positive and significant relationship with FDI flows coming into Africa. A $1 \%$ rise in the commodity price index will lead to an increase of FDI flows into African countries by $0.53 \%$. The performance of the world stock market index has also been found to have a positive and significant relationship with inward FDI to the continent. A $1 \%$ rise in the performance of stock markets in developed countries will lead to an increase of FDI flows into the African continent by $0.58 \%$.

Both gross fixed capital formation (infrastructure) and openness to trade are significant determinants of FDI. These variables have a positive relationship with the FDI inflows as anticipated. A $1 \%$ increase in the level of infrastructure will lead to an increase of FDI flows received into African countries by $0.28 \%$. When the openness to trade variable increases by $1 \%$, this will lead to an increase of FDI into African countries by $0.81 \%$.

The lagged value of FDI is significant in influencing current FDI inflows. The results find that there is a positive relationship between FDI flows received in the previous year by African countries and current FDI inflows into the
Continent. A $1 \%$ increase in the FDI flows received into African countries in the previous year will lead to an increase of FDI flows received in the current year by $0.42 \%$.

\section{CONCLUSION}

The policy implications from this research will be useful to African policy-makers, the various organisations of the AU, central banks, producers and exporters of commodities in African countries as well as investors that would like to obtain more information about investing in Africa.

African nations should ensure that they have strong economic health, openness to trade, and good infrastructure so as to attract inward FDI. Having a low level of political instability and financial health is also beneficial to African countries as this increases investor confidence. African policy-makers are advised that the performance of commodity prices has a positive and significant effect on FDI flows into their nations. This is especially the case for countries that are rich in natural resources. The performance of stock markets in developed countries also has a positive and significant effect on inward FDI flows to African countries. African policy-makers will need to ensure that there are policies in place to cater for increased FDI when commodity prices rise, and/or when stock markets in developed countries are performing strongly.

Foreign investors are inclined to invest in a country that has received foreign investments in the past as this suggests that this country is open to engage in business dealings with other nations. Also, FDI projects tend to last for more than one year thus flowing into the current year. The results from this research indicate that the ICRG economic, financial, and political risk ratings do act as a good proxy for the economic health, financial health, and political stability in African nations.

\section{REFERENCES}

[1] J. Gionea, International Trade and Investment. An Asia-Pacific Perspective, Australia: McGraw Hill Australia Pty Ltd. 440, 2003.

[2] Inward and Outward Foreign Direct Investment Flows, Annual, 1970-2012, 2013, United Nations Conference on Trade and Development.

[3] The Economist. "A more hopeful continent." (January 2011). [Online]. Available: http://www.economist.com/node/17853324

[4] R. Mash, "The investment response to temporary commodity price shocks," Centre for the Study of African Economies Working Paper Series, no. 14, 1998

[5] E. Asiedu, "Foreign direct investment in Africa: The role of natural resources, market size, government policy, institutions and political instability," World Economy, vol. 29, no. 1, pp. 63-77, 2006.

[6] E. Asiedu and D. Lien, "Democracy, foreign direct investment and natural resources," Journal of International Economics, vol. 84, no. 1, pp. 99-111, 2011.

[7] M. Busse and C. Hefeker, "Political risk, institutions and foreign direct investment," European Journal of Political Economy, vol. 23, no. 2, pp. 397-415, 2007.

[8] A. G. Mijiyawa, "What drives foreign direct investments in Africa?" An Empirical Investigation with Panel Data, pp. 25, 2012.

[9] A. E. Ezeoha and N. S. Cattaneo, "FDI flows to sub-saharan Africa: The impact of finance, institutions and natural resource endowment," Comparative Economic Studies, vol. 54, no. 3, pp. 597-632, 2012.

[10] J. C. Anyanwu, "Why does foreign direct investment go where it goes?: New evidence from African countries," Annals of Economics and Finance, vol. 13, no. 2, pp. 433-470, 2012.

[11] A. B. Nabende, "Foreign direct investment determinants in Sub-Sahara Africa: A co-integration analysis," in Economics Bulletin, pp. 1-19, 2002. 
[12] S. Tarzi, "Foreign direct investment flows into developing countries: Impact of location and government policy," The Journal of Social, Political, and Economic Studies, vol. 30, no. 4, pp. 497, 2005.

[13] S. E. Mohamed and M. G. Sidiropoulos, "Another look at the determinants of foreign direct investment in MENA countries: An empirical investigation," Journal of Economic Development, vol. 35 , no. 2 , pp. $75-95,2010$.

[14] S. Onyeiwu and H. Shrestha, "Determinants of foreign direct investment in Africa," Journal of Developing Societies, vol. 20, no. 1-2, pp. 89-106, 2004

[15] Z. Hailu, "Demand Side factors affecting the inflow of foreign direct investment to African countries: Does capital market matter?" International Journal of Business and Management, vol. 5, no. 5, 2010.

[16] F. L. Bartels, S. N. Alladina, and S. Lederer, "Foreign direct investment in Sub-Saharan Africa: Motivating factors and policy issues," Journal of African Business, vol. 10, no. 2, pp. 141-162, 2009.

[17] C. Dupasquier and P. N. Osakwe, "Foreign direct investment in Africa: Performance, challenges, and responsibilities," Journal of Asian Economics, vol. 17, no. 2, pp. 241-260, 2006.

[18] E. Asiedu, "On the determinants of foreign direct investment to developing countries: Is Africa different?" World Development, vol. 30 no. 1, pp. 107-119, 2002

[19] T. Kandiero and M. Chitiga, "Trade openness and foreign direct investment in Africa," South African Journal of Economic and Management Sciences, vol. 9, no. 3, pp. 355-370, 2006.

[20] K. Sekkat and M. A. V. Varoudakis, "Openness, investment climate, and FDI in developing countries," Review of Development Economics, vol. 11 , no. 4, pp. 607-620, 2007.

[21] E. Twimukye, "An econometric analysis of determinants of foreign direct investment: A panel data study for Africa," Economics, Graduate School of Clemson University, 2006, pp. 93.

[22] W. A. Naudé and W. F. Krugell, "Investigating geography and institutions as determinants of foreign direct investment in Africa using panel data," Applied Economics, vol. 39, no. 10, pp. 1223-1233, 2007.

[23] M. B. Nonnemberg and M. J. C. D. Mendonça, "The determinants of foreign direct investment in developing countries," in Proc. the 32th Brazilian Economics Meeting, 2004, no. 061.

[24] A. K. Coleman and K. A. Tettey, "Effect of exchange-rate volatility on foreign direct investment in Sub-Saharan Africa: The case of Ghana," The Journal of Risk Finance, vol. 9, no. 1, pp. 52-70, 2008.

[25] A. A. Sadig, "The effects of corruption on FDI inflows," Cato Journal, vol. 29, no. 2, pp. 267, 2009.

[26] P. Zheng, "A comparison of FDI determinants in China and India," Thunderbird International Business Review, vol. 51, no. 3, pp. 263-279, 2009.

[27] A. Baniak, J. Cukrowski, and J. Herczynski, "On the determinants of foreign direct investment in transition economies," Problems of Economic Transition, vol. 48, no. 2, pp. 6-28, 2003.
[28] R. M. Quazi, "Investment climate and foreign direct investment: A study of selected countries in Latin America," Global Journal of Business Research, vol. 1, no. 1, pp. 1-13, 2007.

[29] What are BITs. (September 2013). [Online]. Available: http://www.unctadxi.org/templates/Page___1006.aspx

[30] E. Neumayer and L. Spess, "Do bilateral investment treaties increase foreign direct investment to developing countries?" World Development, vol. 33, no. 10, pp. 1567-1585, 2005.

[31] T. Büthe and H. V. Milner, "The politics of foreign direct investment into developing countries: Increasing FDI through international trade agreements?" American Journal of Political Science, vol. 52, no. 4, pp. 741-762, 2008.

[32] J. Walsh and J. Yu, Determinants of Foreign Direct Investment: A Sectoral and Institutional Approach, 2010, p. 27.

[33] N. F. Campos and Y. Kinoshita, "Why does FDI go where it goes? New evidence from the transition economies," International Monetary Fund, 2003

[34] G. Biglaiser and K. DeRouen, "The effects of IMF programs on U.S. foreign direct investment in the developing world," The Review of International Organizations, vol. 5, no. 1, pp. 73-95, 2010.

[35] M. U. Karakaplan, B. Neyapti, and S. Sayek, "Aid and foreign direct investment: International evidence," Bilkent University Discussion Paper, 2005.

[36] The World Bank, Gross Fixed Capital Formation (Current US\$), 2013, The World Bank.

[37] E. Aryeetey et al., The Oxford Companion to the Economics of Africa, Oxford University Press, 2012, p. 688

[38] O. Akinkugbe, "A two-part econometric analysis of foreign direct investment flows to Africa," Journal of World Trade, vol. 39, no. 5, pp. 907, 2005.

[39] J. W. Fedderke and A. T. Romm, "Growth impact and determinants of foreign direct investment into South Africa, 1956-2003," Economic Modelling, vol. 23, no. 5, pp. 738-760, 2006.

[40] G. Duca, "The relationship between the stock market and the economy: Experience from international financial markets," University of Malta: Bank of Valletta Review, pp. 12, 2007.

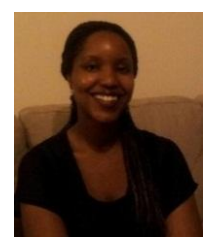

Caroline Kariuki was born in Nairobi Kenya, in 1984 This author obtained her undergraduate degree in economics and financial planning from Curtin University, Perth, Australia in 2006. The author later obtained her master's degree in accounting from the same university in 2007. This author is currently pursuing her $\mathrm{Ph} . \mathrm{D}$. in economics through Curtin University, Perth, Australia. Her research interests are foreign direct investment in Africa, international trade and regiona integration, financial market movements in developed countries and investments into Africa, financial market development in Africa. 